\title{
THE ROLE OF MUSEUMS IN CREATING THE REGION BRAND
}

\author{
Joanna MACALIK \\ Wroclaw University of Economics; joanna.macalik@ue.wroclaw.pl, ORCID: 0000-0003-3946-8834
}

Purpose: The aim of the paper is to analyze the role of museums as specific entities of the cultural market in shaping the region brand.

Methodology: The paper presents the results of a case study and desk research, regarding the role of museums in building the image of the Lower Silesian Voivodeship, supplemented with selected results of quantitative and qualitative own research.

Findings: The analysis showed that increasing the role of museums in building the region brand is in the best interest of both parties and that there are many cooperation methods for museums and regions that bring real benefits.

Practical implications: Looking for a model of cooperation that will be beneficial for both the region and museums and their brands is therefore crucial.

Originality/value: According to the author knowledge, the paper is one of the very first attempts to identify the role of museums in creating the region brand.

Keywords: museums, cultural institutions, region brand, image, place marketing.

Category of the paper: research paper/case study.

\section{Introduction. The region as a brand}

The subject of the presented article is the role of museums in creating the region brand. First of all, it should be noted that the region brand is a much more blurred and less coherent category of place marketing than e.g., a city or a country brand. As Caldwell and Freire wrote, Countries are so functionally diverse, they should leverage the emotive or representational parts of their brand identity, while regions and cities, being smaller in scale, should leverage their more functional facets. It seems that regions have more in common with cities from a branding point of view, and this has implications for branding strategies for all three types of tourist destinations (Freire, and Caldwell, 2004, p. 50). Most regions find resolving key identity issues significantly challenging and, for this reason, until recently, regions less often than cities or countries, decided to conduct their marketing communication. However, 
this situation is slowly changing, and more and more regions are looking for ways to stand out by creating the unique image of their brand.

The purpose of the article is to analyze the potential role that museums can perform in creating a positive region brand. For this purpose, critical literature analysis and desk research methods were used. The article also presents the most relevant results of the case study on the Lower Silesian Voivodeship and fragments of quantitative and qualitative results of both own and secondary research. Due to the complexity of the region brand issue, the focus was mainly set on the issue of creating the region brand image as a tourism brand and on brand communication targeted at domestic and foreign tourists.

\section{Museums in the context of territorial marketing. Research review}

According to the current definition of International Council of Museums, museum is a non-profit, permanent institution in the service of society and its development, open to the public, which acquires, conserves, researches, communicates and exhibits the tangible and intangible heritage of humanity and its environment for the purposes of education, study and enjoyment (ICOM, 2017). Based on this definition, museums are considered within at least four scientific perspectives, located in the field of management science, and, more specifically, in marketing science. These perspectives include:

1. research on the marketing of cultural institutions,

2. research on the marketing of non-profit organizations,

3. tourist market research, treating the museum as a tourist attraction,

4. research on the place marketing.

Each of the above-mentioned perspectives, not only the last one, must assume a fairly significant connection between the activities of a museum institution and the region activities within it operates, due to several reasons, and, above all, to the fact that the vast majority of museums (in Poland 78,3\%) are public institutions dependent on public financing.

The previous scientific literature discussing the subject of museums in the context of the region treats them primarily as a tourist product (Stasiak, 2000; Toczewski, 2006) and only to a small extent does it consider the importance of museums (and cultural institutions in general) for creating the region brand.

Meanwhile, for example, broadly understood cultural life is one of the most important factors influencing the image of the city, in the opinion of its residents, who consider this an important factor attracting tourists (Figure 1) (Adamiczka, and Macalik, 2019). Recent studies also point to the great importance of museums in the context of the national brand (Licona, Calpe, 2018) and the city brand (Hamnett, and Shoval, 2003, pp. 223-226). 


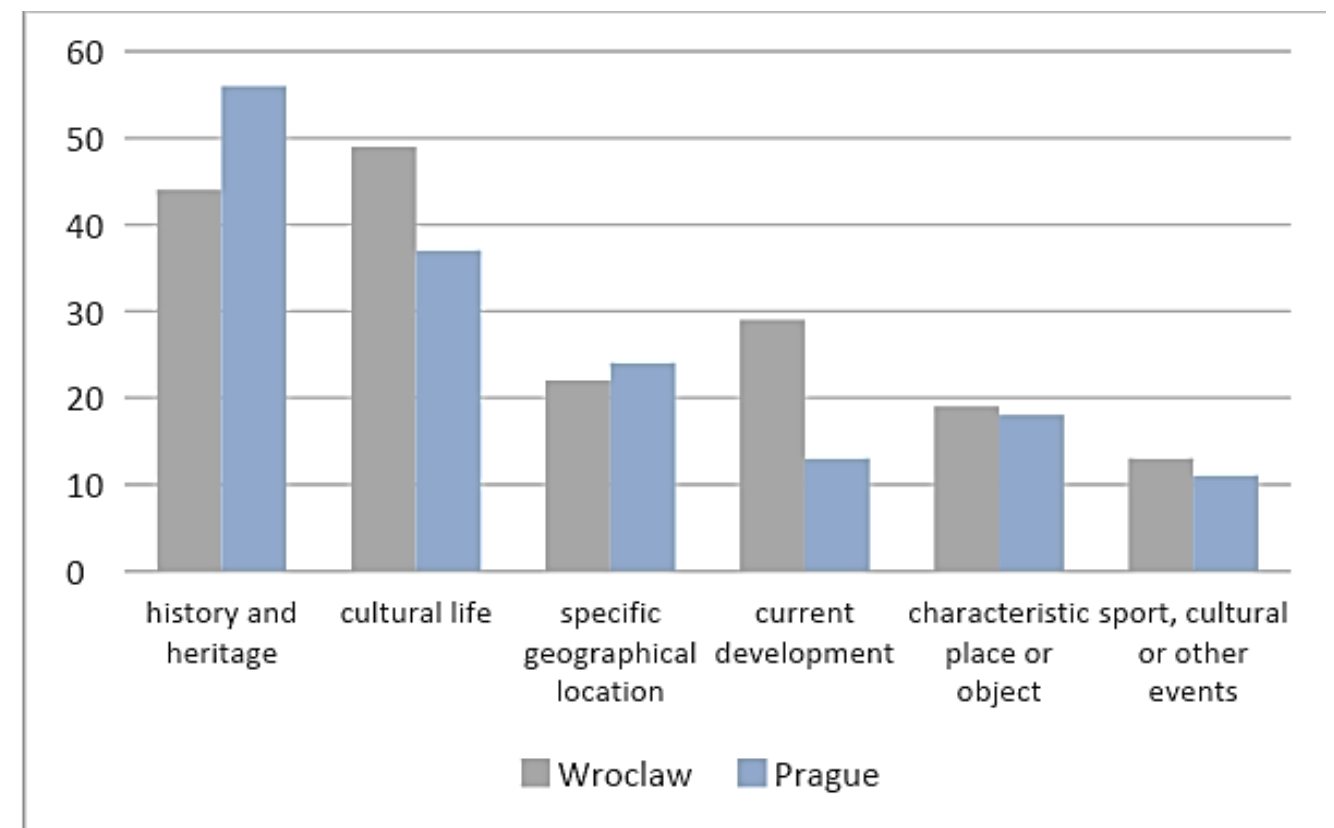

Figure 1. Factors having the most significant impact on the image of the city Wroclaw and Prague by the number of indications. Source: (Adamiczka, and Macalik, 2019).

The scientific literature provides a variety of place brand definitions, as well as place brand management models (Kavaratzis, 2004, 2005; Anholt, 2007; Hanna, and Rowley, 2011, 2013; Balakrishnan, and Kerr, 2013; Berrada, 2018 and others). Basically, scientists compare a place brand to a corporate brand, mainly because a place brand is addressed to different groups of recipients, and it requires conducting planned and systematic activities related to creating and maintaining a positive image of the place (Daszkiewicz, 2017, p. 111). A place brand, and also a region brand, has a particularly complex architecture, which contains submarks and so-called "endorsed brands" and "shadow endorsed brands." For all these elements, the brand of the place constitutes an umbrella brand (Daszkiewicz, 2017, p. 111-112) (Figure 1).

According to the above division, cultural institutions, especially museums, usually operate within the region as its endorsed or shadow endorsed brands. Particularly recognizable museums, especially in an external perspective, can, however, be considered as - even main sub-brands, in particular - of a city or a region. In the scientific literature, the term "emblem museum" is used. It refers to museums, which usually become a mandatory touristic objective and the reason for which a tourist decides to prolong the time spent in a certain city (Corbos, and Popescu, 2011, p. 304). The above definition concerns the external perception of the place brand and locates the museum in the perspective of the city, but certainly there are also museums that have an emblematic meaning, and they become a symbol for the region or even for the country (like The British Museum for England, Galeria Degli Uffizi for Italy or Louvre for France). 


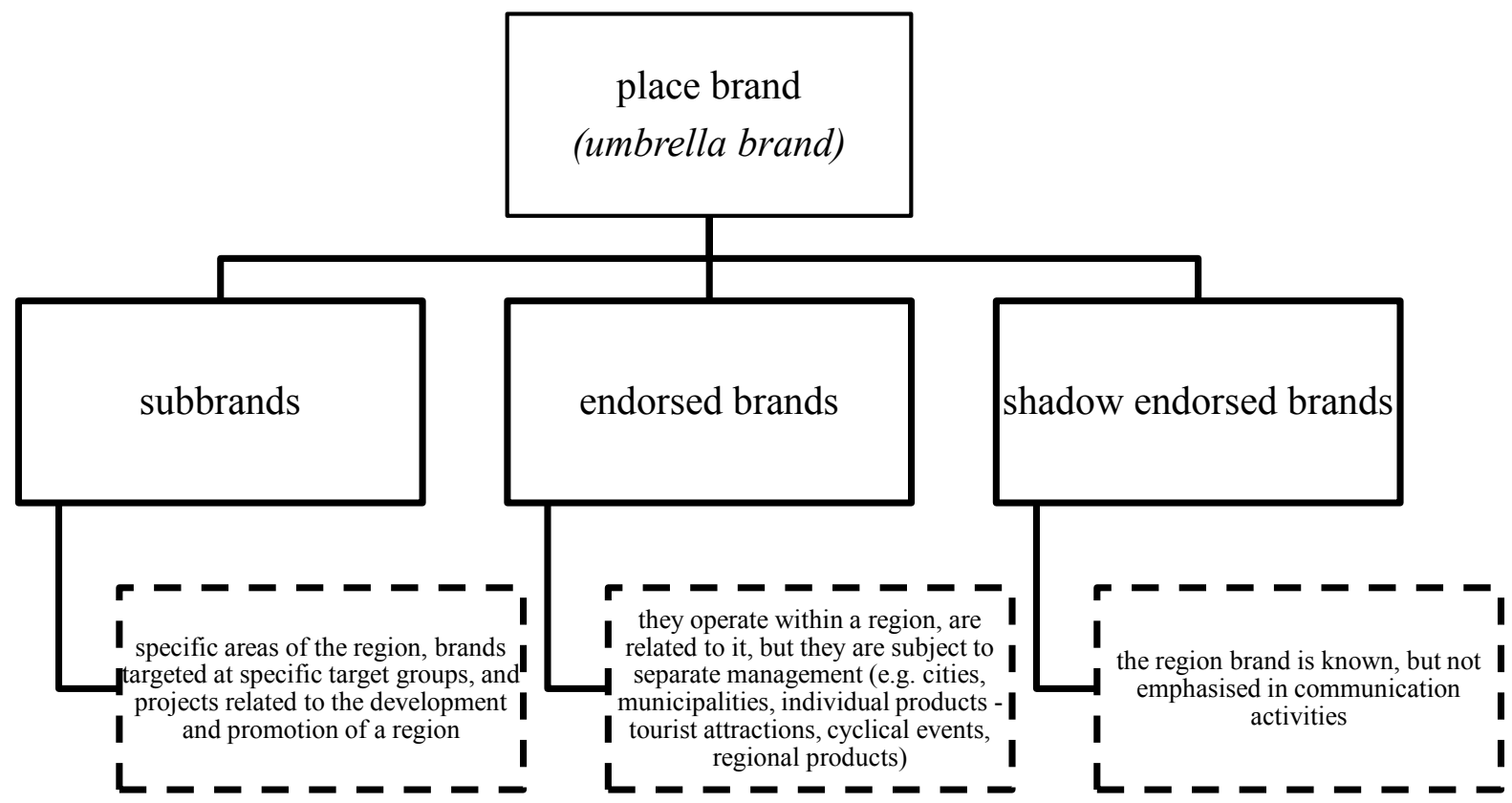

Figure 2. The architecture of the place brand. Adapted from: (Daszkiewicz, 2017, p. 112).

For the above reasons, museums will have the potential to support a positive image of the region brand. This statement applies not only to regional museums, but also to museums with a completely different theme; skillfully used in the communication of the region brand, the museums can highlight its specific features.

One should consider how to verify the role of museums, or more broadly - cultural institutions - in shaping a positive image of the region. As in the case of other place branding issues, also the methods of assessing the power of the place brand often follow into the methods of testing the strength of commercial brands (Dudek-Mańkowska, and Balkiewicz-Żerek, 2015, p. 18). However, there are at least a few methodologies in the scientific literature and the practice of place marketing, trying to capture the specificity of the place brand and the complexity of its sub-brand portfolio. These methodologies use a variety of research methods, both quantitative and qualitative (Chan, and Lawal, 2013), and to varying degrees, take into account the role of culture and cultural institutions in shaping the brand of the place. The vast majority of research focuses on the diagnosis of the place brand image and research on city brands prevails. Table 1. presents an analysis of three selected methodologies of the place brand image evaluation, taking into account the potential role of museums within them.

It should be noted that even though culture is an important factor shaping the brand of a place, according to the presented methodologies, the importance of museums is not emphasized. Also, there is a lack of a methodology that fully reflects the specificity of a region. 
Table 1.

Selected methodologies of place brand evaluation and the role a museum might have performed

\begin{tabular}{|c|c|c|c|}
\hline $\begin{array}{c}\text { Methodology } \\
\text { name }\end{array}$ & $\begin{array}{c}\text { Type of } \\
\text { territorial } \\
\text { unit }\end{array}$ & Short description of the methodology & $\begin{array}{c}\text { Possible role } \\
\text { of museums } \\
\text { in the methodology }\end{array}$ \\
\hline $\begin{array}{l}\text { City Brands Index } \\
\text { TM (CBI)/Anholt- } \\
\text { GfK Nation } \\
\text { Brands Index }\end{array}$ & city & $\begin{array}{l}\text { The index evaluates the power and appeal of } \\
\text { a city's image, providing a holistic and } \\
\text { detailed perspective based on six key } \\
\text { dimensions: } \\
\text { - Presence (the city's international status } \\
\text { and standing), } \\
\text { - Place (its physical outdoors aspect and } \\
\text { transport), } \\
\text { - Prerequisites (basic requirements, such as } \\
\text { affordable accommodations and the } \\
\text { standard of public amenities), } \\
\text { - People (friendliness, cultural diversity, } \\
\text { how safe one feels), } \\
\text { - Pulse (interesting things to do). } \\
\text { - Potential (the economic and educational } \\
\text { opportunities available), }\end{array}$ & $\begin{array}{l}\text { National and } \\
\text { international recognition } \\
\text { of museums (Presence), } \\
\text { characteristic locations } \\
\text { (Place), interesting } \\
\text { events and temporary } \\
\text { exhibitions (Pulse), } \\
\text { artists and museum } \\
\text { professionals as } \\
\text { personalities (People), } \\
\text { educational activities } \\
\text { (Potential). }\end{array}$ \\
\hline $\begin{array}{l}\text { Saffron's European } \\
\text { City Brand } \\
\text { Barometer }\end{array}$ & city & $\begin{array}{l}\text { The analysis looks at two different qualities: } \\
\text { - City asset strength (which asks: looking } \\
\text { only at the observable and measurable } \\
\text { features of the city how strong could the } \\
\text { city's brand be?) } \\
\text { - City brand strength (which asks: right } \\
\text { now, how strong is the city's brand } \\
\text { really?) } \\
\text { The methodology includes } \\
\text { "global buzz," which was measured using } \\
\text { a combination of media mentions and social } \\
\text { media. }\end{array}$ & $\begin{array}{l}\text { The presence of } \\
\text { museums in social media } \\
\text { - in their connection with } \\
\text { the city, objective results } \\
\text { regarding the museum } \\
\text { attendance, exhibits, } \\
\text { events. }\end{array}$ \\
\hline $\begin{array}{l}\text { Bloom } \\
\text { Consulting's CRC } \\
\text { Brand Wheel }\end{array}$ & $\begin{array}{l}\text { nation, } \\
\text { region, city }\end{array}$ & $\begin{array}{l}\text { Bloom Consulting defines five different } \\
\text { objectives: Country, Region, and City (CRC) } \\
\text { Branding objectives or dimensions } \\
\text { (corresponding to a different target group): } \\
\text { - Attraction of Investment } \\
\text { - Attraction of Tourism } \\
\text { - Attraction of Talent } \\
\text { - Strengthening Prominence } \\
\text { - Strengthening Exports. }\end{array}$ & $\begin{array}{l}\text { Tourists' interest in } \\
\text { museum tourism, } \\
\text { attendance at individual } \\
\text { museums, artists and } \\
\text { museum professionals as } \\
\text { talents, the role of } \\
\text { museums in building } \\
\text { publicity of the place. }\end{array}$ \\
\hline
\end{tabular}

Source: own study based on (Saffron, 2019; Bloom Consulting, 2018; GFK Global, 2016; DudekMańkowska and Balkiewicz-Żerek, 2015).

In the following part of the article, the above theoretical considerations will be supplemented by the case study analyzing the role of museums in creating the image of the Lower Silesia region (administratively - Lower Silesian Voivodeship). 


\section{The role of museums in creating the Lower Silesian Voivodeship. The region perspective}

The Lower Silesian Voivodeship is one of the 16 voivodeships (provinces) into which Poland is divided. It is a region with great tourist potential and an attractive cross-border location in the southwest of the country. It is the seventh-largest area $(19,947 \mathrm{sq} \mathrm{km})$ voivodeship in Poland, and the fifth in terms of the number of inhabitants (2.9 million) (Lower Silesian Governor's Office [Urząd Marszałkowski Województwa Dolnośląskiego], 2018a). The area of the province includes the western part of historic Silesia, as well as the Kłodzko region, eastern Upper Lusatia, and a small section of historical Saxony (Bogatynia and its surroundings). Lower Silesia belongs to the most diverse in nature and landscape regions of Poland and is also characterized by the richness of material culture heritage, which results in a rich (Table 2) and diverse (Table 3 ) museum offer.

Table 2.

Museums in Lower Silesian Voivodeship

\begin{tabular}{|l|l|l|l|l|l|}
\hline \multicolumn{1}{|c|}{ Specification } & \multicolumn{1}{c|}{$\mathbf{2 0 1 0}$} & \multicolumn{1}{|c|}{$\mathbf{2 0 1 5}$} & $\mathbf{2 0 1 6}$ & \multicolumn{1}{|c|}{$\mathbf{2 0 1 7}$} & \multicolumn{1}{|c|}{$\mathbf{2 0 1 8}$} \\
\hline Museums and branches & 58 & 67 & 72 & 74 & 73 \\
\hline Museum and exhibition visitors in thous & 1689,7 & 1838,1 & 2007,7 & 1978,1 & 2035,7 \\
\hline
\end{tabular}

Adapted from: (Main Statistical Office [Główny Urząd Statystyczny], 2018).

Table 3.

Types of the museums in Lower Silesia Voivodeship in 2018

\begin{tabular}{|l|l|l|l|}
\hline Type of the museum & Number of museums & & \\
\hline artistic & 12 & natural & 3 \\
\hline technology and sciences & 11 & interdisciplinary & 3 \\
\hline regional & 10 & ethnographical & 1 \\
\hline historical & 8 & biographical & 1 \\
\hline military & 7 & literary & 1 \\
\hline geological & 5 & martyrological & 1 \\
\hline other & 5 & open-air & 1 \\
\hline archeological & 4 & interior & 0 \\
\cline { 2 - 4 } & total & 73 \\
\cline { 2 - 4 }
\end{tabular}

Typology of museums, according to the "Report on the activities of the museum and the paramuseal institution 2018" (K-02). Adapted from: (Main Statistical Office [Główny Urząd Statystyczny], 2018).

For about ten years, Lower Silesia has been consistently investing in its brand building and developing its communication. Just like the touristic, investment, and housing offer of the region, its brand also has a very complex structure. It results from the heterogeneous identity of the voivodeship, both in historical and cultural terms. Among many elements that constitute the voivodeship brand, cultural institutions, especially museums, play a minor role. The considerable number of museums and their wide range are not reflected in the official brand communication of the region. 
First of all, it should be noted that the offer of cultural tourism, including museum tourism, is not of interest to the authors of strategic documents of the voivodeship. Conducted desk research showed that that key documents (Lower Silesian Governor's Office [Urząd Marszałkowski Województwa Dolnośląskiego], 2018b, 2018a) on regional development and increasing the tourism potential of the region do not, or if, then to a minimal extent, address the issue of museum tourism.

However, museums are of little interest to the document entitled "Image communication strategy of the province Lower Silesia in the country and abroad for 2016-2020" (Lower Silesian Governor's Office [Urząd Marszałkowski Województwa Dolnośląskiego], 2016). In the document, significant premises indicating that museums are an important factor in creating the region brand image can be found. These are:

- willingness to strengthen the image of the region as a place of extraordinary cultural values among the priorities of the tourist microsphere,

- drawing attention to the fact that the National Museum in Wroclaw ranks fifth among the most-visited tourist attractions of the region,

- indication of consumer trends related to increasing tourists' interest in museums, such as long-life learning or the renaissance of patriotic attitudes,

- mentioning cultural tourism as a tourist sub-product of the region,

- recognizing that the subject matter of collections and the nature of exhibitions in museums often directly refer to the place where the museum is located (numerous regional, monastery or castle museums).

So far, the most significant image campaigns of the Lower Silesian Voivodeship in turn - "Mysterious Lower Silesia. Indescribable - see you soon", "Lower Silesia. Touch the secret" and "Let's discover Lower Silesia together," conducted in 2012 and 2013 (Lower Silesian Governor's Office [Urząd Marszałkowski Województwa Dolnośląskiego], 2013) did not refer to the museum offer of the region. It included the broadcast of spots on nationwide TV stations, in cinemas and in leading internet portals, as well as a billboard campaign and citylights in the largest Polish cities. Although both TV spots and outdoor advertisements present the cultural heritage of Lower Silesia, among the examples presented in the campaigns there was not a single example of a museum from the region.

The Lower Silesia museum offer can support the brand attributes indicated in the communication strategy (Lower Silesian Governor's Office [Urząd Marszałkowski Województwa Dolnośląskiego], 2016, pp. 45-46). The selection is presented in Table 4, together with exemplary assigned museums corresponding to individual attributes.

Therefore, it should be stated that museums have great opportunities to support the region brand attributes. However, they must be skillfully incorporated into the image of the region, taking into account the individual interests of individual institutions. 
Table 4.

Museums and attributes of Lower Silesia Brand

\begin{tabular}{|c|c|c|}
\hline $\begin{array}{l}\text { Selected Lower Silesia } \\
\text { brand attribute }\end{array}$ & Possible support from museums & $\begin{array}{c}\text { Examples of museums and their } \\
\text { actions }\end{array}$ \\
\hline \multicolumn{3}{|c|}{ Hard attributes } \\
\hline $\begin{array}{l}\text { European cultural } \\
\text { heritage }\end{array}$ & $\begin{array}{l}\text { The exhibitions of many museums show the } \\
\text { interpenetration of cultures, the variability of } \\
\text { administrative boundaries and nationality, and } \\
\text { numerous exhibits of European significance. }\end{array}$ & $\begin{array}{l}\text { National Museum in Wroclaw, } \\
\text { Museum Gross-Rosen, Museum } \\
\text { of Ceramics in Boleslawiec. }\end{array}$ \\
\hline $\begin{array}{l}\text { Cultural and natural } \\
\text { landscape }\end{array}$ & $\begin{array}{l}\text { Historic urban layouts, temples, castles, and } \\
\text { palaces in which museums operate. }\end{array}$ & $\begin{array}{l}\text { Bolkow Castle Museum, Museum } \\
\text { of Industry and Railway in Silesia } \\
\text { in Jaworzyna Śląska. }\end{array}$ \\
\hline Dynamic Wroclaw & $\begin{array}{l}\text { New, spectacular museum investments in the } \\
\text { capital of Lower Silesia and the region }\end{array}$ & $\begin{array}{l}\text { National Museum in Wroclaw - } \\
\text { Four Domes Pavilion. }\end{array}$ \\
\hline \multicolumn{3}{|c|}{ Soft attributes } \\
\hline Mystery & Narrative support for the region mystery. & $\begin{array}{l}\text { Riese Military Technology } \\
\text { Museum, The Karkonoskie } \\
\text { Museum in Jelenia Góra, } \\
\text { Wroclaw City Museum. }\end{array}$ \\
\hline Passion for creation & $\begin{array}{l}\text { Presentations of former and present } \\
\text { outstanding artists and patrons. }\end{array}$ & $\begin{array}{l}\text { Planned exhibition "Willmann } 1 . \\
\text { Opus magnum" in the National } \\
\text { Museum in Wroclaw. }\end{array}$ \\
\hline
\end{tabular}

Own elaboration based on: (Ministry of Culture and National Heritage [Ministerstwo Kultury i Dziedzictwa Narodowego], 2019; Lower Silesian Governor's Office [Urząd Marszałkowski Województwa Dolnośląskiego], 2016, pp. 45-46).

\section{The role of museums in creating the Lower Silesian Voivodeship. The museums perspective}

The role of museums in building the region brand from a regional perspective was presented above. In the following part of the article, this matter will be presented from the museum perspective.

According to the results of the research conducted by the author, museums are more frequently implementing modern management methods, and thus, they are also increasingly interested in building and maintaining long-term and positive relationships with their entire environment. Among the key environmental entities with which museums want to have longterm relationships, are primarily the media - mainly local ( $90 \%$ of museums) and in the second place - local and regional authorities (71\%), as well as associations and foundations operating in the region $(54 \%)^{2}$. The qualitative research conducted by the author - individual in-depth interview among marketing managers in museums - showed that interest in cooperation with the authorities is due to several reasons, out of which the most important are:

\footnotetext{
${ }^{1}$ Michael Lucas Leopold Willmann - German painter active in Lower Silesia at the turn of the seventeenth and eighteenth centuries, often called "Silesian Rembrandt".

${ }^{2}$ A survey conducted on a group of 85 marketing managers in museums in July 2017. Source: (Macalik, 2018).
} 
- willingness to create a local or regional cooperation network,

- striving to increase interest in the museum's offer among tourists and residents of the region,

- increasing the chances of acquiring patrons and sponsors.

Cooperating within the region, museums can reap the benefits of being more visible in its brand portfolio. This can be done, among others, by various initiatives integrating the activities of museums in the region.

There are few such projects in Lower Silesia. One of them is the action "\#muzealniaki/ \#musekids" (Pan Tadeusz Museum [Muzeum Pana Tadeusza], 2019). The Pan Tadeusz Museum, by initiating the \#muzealniaki campaign, wants to show that it is never too early to interact with culture, and a visit to a museum or art gallery can also be interesting for parents with the youngest children. Partners who declare a friendly attitude towards children's visits numerous museums and art galleries from Lower Silesia - have joined the \#muzealniaki campaign (Pan Tadeusz Museum [Muzeum Pana Tadeusza], 2019). So far, however, the campaign does not involve visible discounts, rebates or loyalty programs, nor it is visibly supported by the region or its major cities.

It should also be noted that the selected museums have more potential to become a sub-brand of the region. They are above all:

- museums that are cultural institutions of the Lower Silesian Voivodeship,

- biggest museums with a great number of original exhibits, and a substantial marketing budget,

- museums with unique themes (on a continental and world scale),

- regional museums, strongly thematically related to the history and culture of the region,

- original museums in terms of the type of exhibition, museum object, or its location.

\section{Conclusions}

The above analysis showed that increasing the role of museums in building the region brand is in the best interest of both parties. The museum brand has a strong set of positive attributes and offers the benefits of discovery, inspiration, excitement, awe, reflection, and perspective. For communities, it provides a window onto history and the sense of identity and belonging that accompanies that journey (Scott, 2007, p. 11).

Looking for a model of cooperation that will be beneficial for both the region and museums and their brands is therefore crucial. Especially that activities of foreign place brands provide some solutions for this type of cooperation. For example, France has created the seventeenmember International French Agency of Museums in order to promote its museums as brands, 
like Musee d'Orsay; the new Musée du Quai Branly; Château de Versailles (Licona, Calpe, 2018).

In conclusion, it should be noted that there are many cooperation methods for museums and regions that bring real benefits. From museums' point of view, possible methods of cooperation will be above all:

- creating cooperation networks,

- matching own marketing, communication strategies to the region brand attributes,

- and from regions' point of view, possible methods of cooperation are:

- using museums' theme in marketing communication,

- encouraging museums to refer to brand attributes in marketing communications, temporary exhibitions, and others.

- stimulating cooperation between museums in the region.

The cooperation methods listed above will result in numerous benefits for both parties. For museums it will be primarily greater recognition of the museum brand among the inhabitants of the region and tourists, and for the region - the greater brand recognition of the region in the country and abroad and strengthening the positive attributes of the region brand, especially those related to its historical and cultural identity.

The analysis points out that regions should show interest in creating a culture for the sub brand and the existence of museums supporting brand attributes should be reflected in regional brand strategies. The basic principle of creating a brand is its uniqueness. According to this principle, a recipient should be convinced that there is no such other product on the market. As Zdon-Korzeniowska notes, in relation to the region brand, it is crucial to create the brand by referring to the already existing regional identity, natural, historical or cultural heritage of the region, which guarantees uniqueness, and therefore facilitates standing out on the global market (Zdon-Korzeniowska, 2012, p. 140). One of the elements that can emphasize the identity and history of the region are museums - hence they should remain in the area of interest of decisionmakers involved in marketing communications, who should look for possible areas of cooperation. Such cooperation between museums and region can contribute to a success also in economic terms - increasing the competitiveness of the region in competition for access to various types of external benefits, such as investment location or obtaining EU funds. 


\section{References}

1. Adamiczka, H., Macalik, J. (2019). The river's role in the city's brand image - a case of Wroclaw (Poland) and Prague (Czech Republic). Proceedings of International Business Information Management Conference (33rd IBIMA) Granada, Spain, 10-11 April 2019, 5525-5539.

2. Bloom Consulting (2018). Country Brand Ranking. Retrieved from https://www.bloomconsulting.com/en/pdf/rankings/Bloom_Consulting_Country_Brand_Ranking_Tourism.pdf.

3. Chan, C.-S., Lawal, M. (2013). A review of place branding methodologies in the new millennium. Place Branding and Public Diplomacy, 9(4), 236-253. https://doi.org/10.1057/ pb.2013.17.

4. Corbos, R.-A., Popescu, R.I. (2011). Museums, marketing, tourism, and urban development. The British museum - a successful model for Romanian museums. Management and Marketing Journal, 2, 303-314.

5. Daszkiewicz, M. (2017). Kreowanie marki regionu - możliwości i wyzwania. Marketing i Rynek, 10, 109-116.

6. Dudek-Mańkowska, S., Balkiewicz-Żerek, A. (2015). Siła marki miejsca. Marketing i Rynek, 6, 14-23.

7. Freire, J.R., Caldwell, N. (2004). The differences between branding a country, a region, and a city: applying the Brand Box Model. Journal of Brand Management, 12 (August 2004), 50-61. https://doi.org/10.1057/palgrave.bm.2540201.

8. GFK Global (2016). Place branding research. Retrieved from https://www.gfk.com/ fileadmin/user_upload/dyna_content/US/documents/The_Place_Branding_Slipsheet.pdf.

9. Hamnett, C., Shoval, N. (2003). Museums as flagships of urban development. In: L.M. Hoffman, S.S. Fainstein, D.R. Judd (Eds.), Cities and Visitors (pp. 219-238). Oxford: Blackwell.

10. ICOM (2017). International Council Of Museums Statutes.

11. Kultura w 2018 roku (2019). GUS.

12. Licona, Calpe, W.M. (2018). National branding and museums: the strategic administration of culture. The Museum Review, 3(1).

13. Lower Silesian Governor's Office [Urząd Marszałkowski Województwa Dolnośląskiego]. (2013). Nowe miejsca promuja Dolny Ślask. Retrieved from http://www.umwd. dolnyslask.pl/aktualnosc/single-view/artykul/nowe-miejsca-promuja-dolny-slask/.

14. Lower Silesian Governor's Office [Urząd Marszałkowski Województwa Dolnośląskiego]. (2016). Strategia komunikacji wizerunkowej województwa dolnośląskiego w kraju i za granica na lata 2016-2020. Retrieved from http://www.umwd.dolnyslask.pl/ fileadmin/user_upload/Biuro_Prasowe/Styczen_2017/Strategia_komunikacji_wizerunkow ej_wojewodztwa_dolnoslaskiego_w_kraju_i_zagranica_na_lata_2016-2020..pdf. 
15. Lower Silesian Governor's Office [Urząd Marszałkowski Województwa Dolnośląskiego]. (2018a). Projekt strategii rozwoju Województwa Dolnośląskiego 2030. Retrieved from http://www.umwd.dolnyslask.pl/fileadmin/user_upload/Rozwoj_regionalny/SRWD/projek t_strategii/Projekt_Strategii_Rozwoju_Wojewodztwa_Dolnoslaskiego_2030.pdf.

16. Lower Silesian Governor's Office [Urząd Marszałkowski Województwa Dolnośląskiego]. (2018b). Strategia Rozwoju Województwa Dolnośląskiego 2020. Retrieved from http://www.umwd.dolnyslask.pl/fileadmin/user_upload/Rozwoj_regionalny/SRWD/SRW D_2020-final.pdf.

17. Macalik, J. (2018). Zintegrowana komunikacja marketingowa w działalności muzeów (Doctoral dissertation). Wroclaw University of Economics, Facluty of Ecnomomics.

18. Main Statistical Office [Główny Urząd Statystyczny] (2018). Statistical Yearbook of Dolnoslaskie Voivodship (together with unpublished data for 2018 received individually).

19. Ministry of Culture and National Heritage [Ministerstwo Kultury i Dziedzictwa Narodowego] (2019). Wykaz muzeów. Retrieved from http://bip.mkidn.gov.pl/pages/ rejestry-ewidencje-archiwa-wykazy/rejestry-muzeow.php.

20. Pan Tadeusz Museum [Muzeum Pana Tadeusza] (2019). \#MUSEKIDS. Retrieved from https://muzeumpanatadeusza.ossolineum.pl/en/program-edukacyjny/muzealniaki.

21. Saffron (2019). City Brand Barometer. Retrieved from https://saffron-consultants.com/ insights/6086/.

22. Scott, C. (2007). What difference do museums make? Using values in sector marketing and branding. Retrieved from http://network.icom.museum/fileadmin/user_upload/minisites/ mpr/papers/2007-scotttxt.pdf.

23. Stasiak, A. (2000). Muzeum jako produkt turystyczny. In: A. Schwichtenberg, E. Dziegieć (Eds.), Przemyst turystyczny (pp. 165-182). Wydawnictwo Politechniki Koszalińskiej.

24. Toczewski, A. (Ed.) (2006). Rola muzeów w turystyce i krajoznawstwie. Wydawnictwo Muzeum Ziemi Lubuskiej w Zielonej Górze.

25. Zdon-Korzeniowska, M. (2012). Budowa marki regionalnej na wybranych przykładach województw Polski. Prace Komisji Geografii Przemystu, 19, 130-141. 